\title{
Suitability of finger jointed structural timber for construction
}

\author{
S. De Silva*, V. Liyanage \\ University of Ruhuna, Department of Civil and Environmental Engineering, Galle, Sri Lanka
}

\begin{abstract}
Timber is widely used as a building material in the construction industry. As it is in short supply, there is now a high demand for timber in the construction industry. This has made waste timber utilization for construction important. Finger jointing can be used to connect two small pieces of waste timber. Machinery is now available in Sri Lanka to fasten, using finger jointing, the timber pieces that are used for the manufacture of furniture. As it is important to determine the structural properties of finger jointed timber, three point bending and compression tests using a Universal Testing Machine (UTM) were conducted on samples of selected timber species commercially available in Sri Lanka, in accordance with British Standard 73:1957 to determine these properties. Samples were finger jointed with a finger length of $19 \mathrm{~mm}$ using the adhesive, Fevicol SWR. Satin with its high resistance to bending is found to be the most suitable species for finger jointing. The tests carried out indicated that when finger jointed, the bending strength of Satin gets reduced by only $9.5 \%$. In the compression parallel to grain test, Jak displayed the minimum reduction of $1.53 \%$ in its compressive strength. In the timber species tested, finger jointing was found to be $100 \%$ effective in resisting compression perpendicular to grain. The compressive strength of Pine is found to be increased by $27.39 \%$ when it is under compression perpendicular to grain. Strength classes of the timber species selected were identified from British Standard 5268-2:2002. According to the results of the statistical analysis made on the mechanical (both experimental and theoretical) properties of timber species available in Sri Lanka, Satin, Pine and Grandis are found to be suitable for finger jointing for use as structural elements. The compressive strength of finger jointed Grandis and Pine are found to be too poor for use as structural elements. Finger jointing of Teak is found to be cost effective. Finally, it is recommended that further studies be done on using finger jointed local timber waste.
\end{abstract}

\section{Keywords}

Waste timber; Finger joint; Local timber species; Strength properties; Economic analysis; Timber utilization Received: 04 June 2019; Accepted: 27 August 2019

ISSN: 2630-5763 (online) ㅇ 2018 Golden Light Publishing ${ }^{\circledR}$ All rights reserved.

\section{Introduction}

Timber is used as a building material in building construction. Waste timber material and short sections of timber dumped by sawn mills are creating many problems in the construction industry. It is therefore necessary to effectively use the timber residues produced in building construction. Timber wastage can be minimized by

\footnotetext{
Corresponding author

E-mail: sudhira@cee.ruh.ac.lk
}

using proper machines and adopting new technologies [1].

Joining of timber pieces longitudinally using fingered end joints as shown in Fig. 1 has been recognized as a qualitative and profitable method for producing high quality timber sections of required length and for reducing timber waste. Through finger jointing, undesirable timber sections can be removed to improve the strength 
and appearance of the timber product. Therefore, finger jointing is an ideal way for improving the efficiency of sawn mills as it minimizes waste of timber [2].

Most of the locally available timber species are hardwood. Although there have been several studies done in the past on the strength of finger jointed sections of softwood, only few such studies have been done on hardwood. Finger jointing is already being used in Sri Lanka to produce nonstructural timber products such as furniture. The mechanisms and machinery required to perform this finger jointing on hardwood are already available in the country. Because of its good structural performance, finger jointed hardwood can be recommended for use as structural elements by the construction industry in Sri Lanka.

Past studies have identified that the structural performance of finger joints (FJs) in order to manufacture finger jointed timber products such as stunts, trusses, columns, beams etc. Joint strength is directly affected by wood quality and there is less strength in finger joint which are prepared by using wood that is below average density than the higher density wood. Therefore, higher density woods are effective for structural finger joint [3]. While considering the structural performance of a finger jointed section, finger jointed $2 \times 4$ " timber can be used as studs in light frame construction and it has been evaluated by testing the studs for static bending [3].

Structural finger jointed studs are offered by Universal Forest Product in order to utilize the timber waste by using entire tree for the products [4].

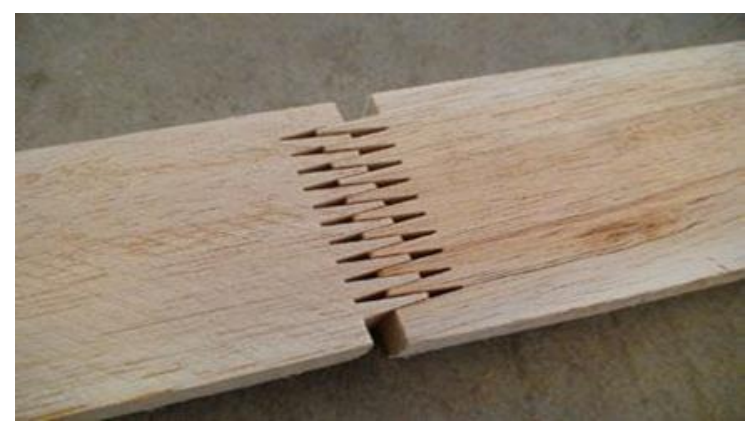

Fig. 1. A finger jointed timber section
They use National Design Specification 1997 as code and design values and grade for the studs are as same as unjointed lumber. A Canadian research evaluated the structural performances of finger jointed black spruce lumber with different joint configurations. Black spruce is used for the engineering wood products in Canada and to use wood more efficiently with finger joint, three joint configurations; feather, male-female and reversed were analyzed according to the Canadian standards requirements and feather configuration is the best for horizontal structural joints [5].

Strength properties of finger jointed timber was assessed to evaluate the influence of number of joints and position of the finger joint with the use of Polymer Isocyanate adhesive and it has been found that mid span is the best location to make a finger joint [6]. MOE was not varied with number of finger joints and the position of the finger joint but MOR is inversely proportional to the number of finger joints in the specimen. But while preparing a structural member with finger joint, it is necessary to position the joint as non-critical point. Finger jointed member has no effect on compression strength but considerably poor in tension compared with a clear timber specimen [6].

Since British Standard (BS) Design Codes do not refer to timber connections done using finger jointing, this study focused on determining the bending properties, compressive strength and Modulus of Elasticity (MOE) of finger jointed sections. The study used timber species commonly available in Sri Lanka to determine their strengths and strength grades for use in structural applications. To understand the behavior of finger connected joints when they are under actual loading conditions, structural scale specimens were tested for compression. In addition, a cost benefit analysis was done on these specimens to determine their cost effectiveness by comparing the performance of clear and glue jointed timber sections. 


\section{Methodology}

\subsection{Sample of collection}

State Timber Corporation (STC) [7] has graded Teak, Jak, Mahogany, Grandis, Satin and Kumbuk as the most used hardwood in Sri Lanka. Similarly, Pine has been graded as the most used softwood in the country. Thus, samples made from sections of Teak, Jak, Mahogany, Grandis, Satin, Kumbuk and Pine that were discarded as waste at the Sawn Mill of STC in Galle were used for the tests. The long sections of timber identified from the waste timber at STC for making the samples were visually inspected to ensure that they were defect free and strong enough for jointing.

\subsection{Specimen preparation}

Specimens for the bending and compression (parallel and perpendicular to grain) tests conducted as Test Series 1 were prepared in accordance with BS 373:1957. Each finger jointed timber specimen had a finger length of $19 \mathrm{~mm}$, tip width of $1.0 \mathrm{~mm}$, tip gap of $0.2 \mathrm{~mm}$ and a pitch of $4.5 \mathrm{~mm}$. The control specimens used for the tests were made of clear timber species and had the same dimensions as the finger jointed specimens.

The specimens were finger jointed at mid span under normal exposure conditions using Fevicol SWR water resistive adhesive.

For the compression tests in Test Series 2, specimens of clear, finger jointed and normal glue jointed sections of non-standard timber sections were prepared at STC, Galle. Finger cutting machinery of the STC were used to machine the specimens (Fig. 2).

\subsubsection{Specimens used in the three-point bending test}

Finger jointed and clear timber specimens used in the three-point bending test were $20 \mathrm{~mm} \times 20$ $\mathrm{mm}$ in cross section and $300 \mathrm{~mm}$ in length (Fig. 3).
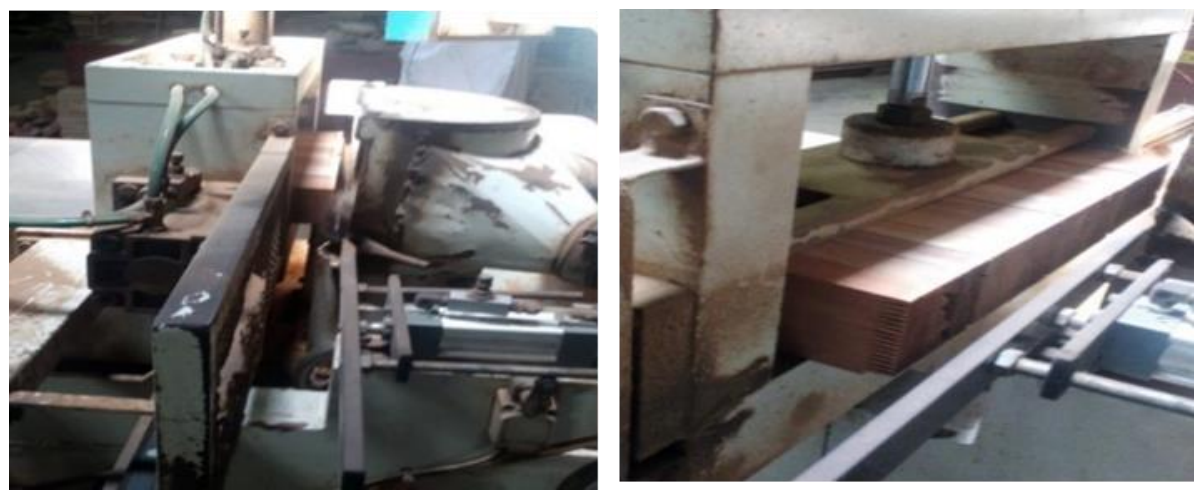

Fig. 2. Finger cutting machines

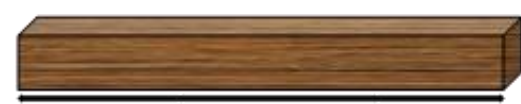

$300 \mathrm{~mm}$

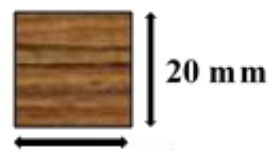

$20 \mathrm{~mm}$

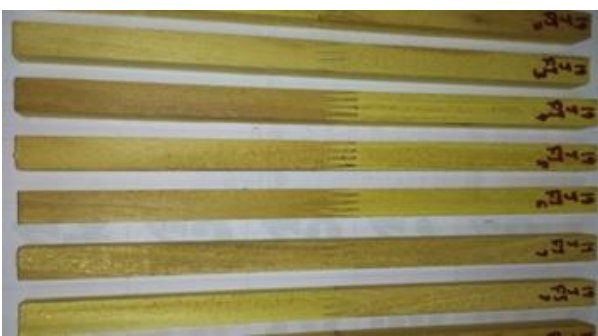

(b) Finger jointed timber specimen

(a) Sample size used in the test

Fig. 3. Specimen used in the three-point bending test 
2.2.2. Specimen used in the compression parallel to grain test

Finger jointed and clear timber specimens used in the compression parallel to grain test were $20 \mathrm{~mm} \times$ $20 \mathrm{~mm}$ in cross section and $60 \mathrm{~mm}$ in length (Fig. $4)$.

\subsubsection{Specimen used in the compression perpendicular to grain test}

The length, width and depth of the specimens of both clear and finger jointed timber used in the compression perpendicular to grain test were each $50 \mathrm{~mm}$ (Fig. 5).

\subsubsection{Specimens of structural scale}

For the Test Series 2, $1000 \mathrm{~mm} \times 100 \mathrm{~mm} \times 100$ $\mathrm{mm}$ finger jointed and glue jointed structural scale specimen were made by Grandis and Pine species as shown in Fig. 6. Clear timber specimens of the same dimensions made of same species of timber were used as the control samples.

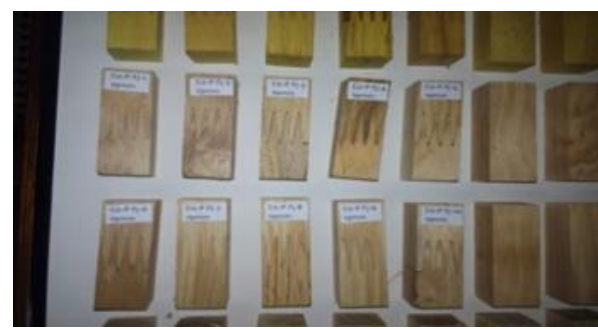

(b) Finger jointed timber specimen

(a) Sample size used in the test

Fig. 4. Specimen used in the compression parallel to grain test

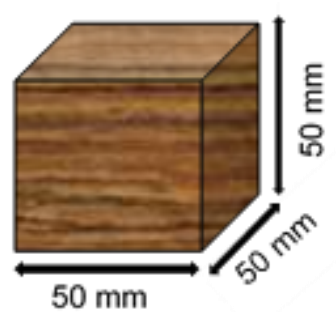

(a) Sample size used in the test

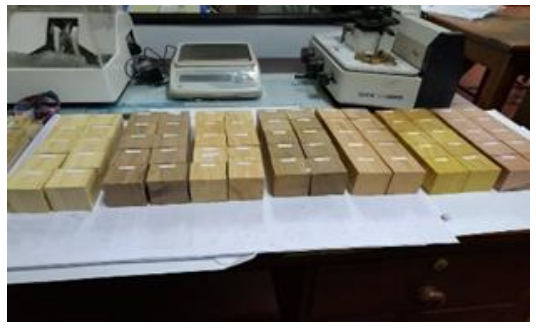

(b) Finger jointed timber specimen

Fig. 5. Specimen used in the compression perpendicular to grain test

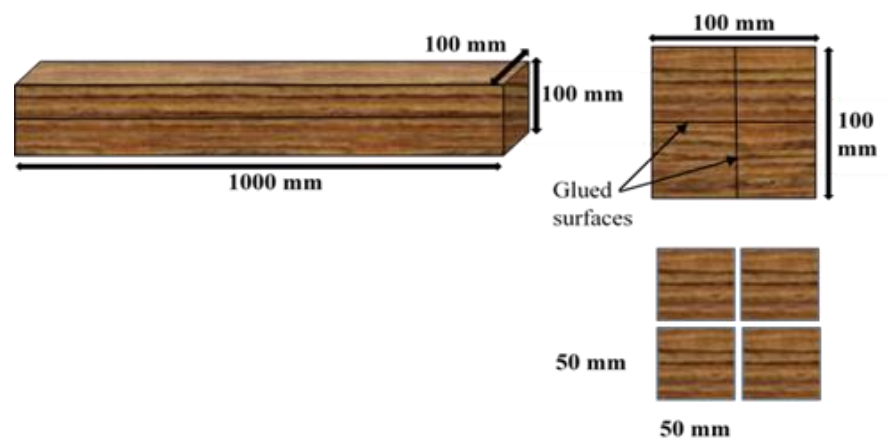

(a) Sample size

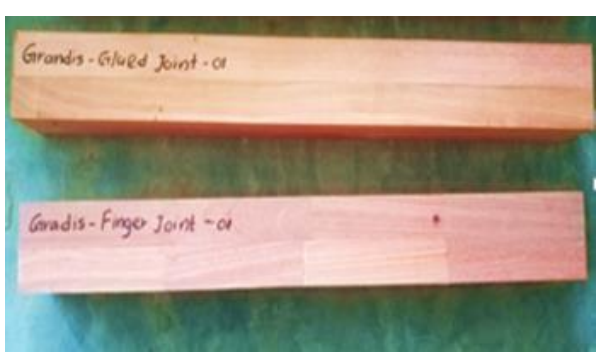

(b) Finger jointed timber specimen

Fig. 6. Structural scale specimen 


\subsection{Experimental procedure}

The three-point bending and uniaxial compression tests of Test Series 1 were conducted on the specimens in accordance with BS 373:1957 Code of Practice, using a universal testing machine (UTM) (Fig. 7). A compression testing machine was used in Test Series 2 to determine the ultimate axial compression capacity of the large nonstandard specimens. Before applying the load through the UTM, the average density and natural moisture content of the specimens of each species were measured.

\subsubsection{Three-point bending test}

Specimens having a span length of $280 \mathrm{~mm}$ were tested for their bending strength using the threepoint bending test. As shown in Fig. 8, the load was applied on the specimens at their mid spans with a loading speed of $0.0066 \mathrm{~m} / \mathrm{min}(0.1 \mathrm{~mm} / \mathrm{s})$. The displacements of the specimens were recorded to obtain their load - displacement curves. Bending strength was calculated at the elastic limit assuming it as the serviceability limit state. The maximum load possible in the elastic region represents the serviceability limit state load.

\subsubsection{Compression parallel to grain test}

Compression parallel to grain test with the loading plate moving at a speed of $0.000635 \mathrm{~m} / \mathrm{min}(0.01$ $\mathrm{mm} / \mathrm{s}$ ) was carried out on the specimens as shown in Fig. 9 to see how their displacements varied with the load. The maximum possible load at the elastic limit was used to obtain the serviceability limit state compressive strength.

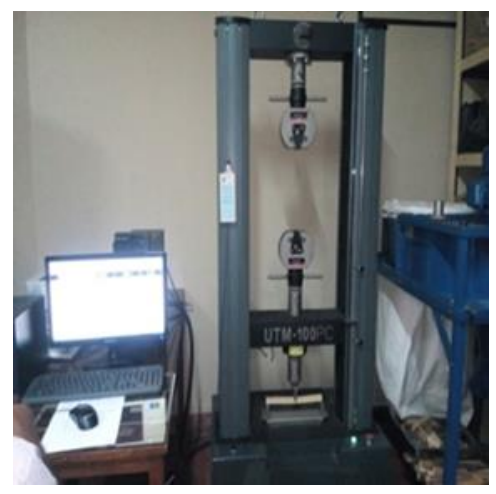

Fig. 7. Universal testing machine

\subsubsection{Compression perpendicular to grain test}

The specimens were loaded perpendicular to grain as shown in Fig. 10 with the loading plate moving at a speed of $0.000635 \mathrm{~m} / \mathrm{min}(0.01 \mathrm{~mm} / \mathrm{s})$ to obtain their displacements. The maximum possible load in the elastic region was used to obtain the serviceability limit state compressive strength.

\subsubsection{Compression test on specimens of structural scale}

The specimens were tested for compression parallel to grain by using a compression testing machine as shown in Fig. 11 and their lateral deflections were recorded as the load varied. The lateral deflections were measured using deflection gauges attached to the specimens.

\subsubsection{Economic analysis}

In the case of economic analysis, cost for manufacturing of linear meter of $100 \mathrm{~mm} \times 100 \mathrm{~mm}$ (4"x4") finger jointed sections for different types of timber species were considered and those are compared with glued and clear timber section. Finger joint manufacturing procedure by waste timber at STC Sawn mill in Galle, Sri Lanka has been considered.

\section{Results and discussion}

\subsection{Bending strength}

Table 3 presents the three-point bending test results and Fig. 12 presents the bending strength variation of clear and finger jointed timber species. The bending strength of Teak, Satin and Pine got reduced by less than $20 \%$ under this test. These results reveal that finger jointed Satin is the timber species that can withstand the bending most.

According to BS 5268-2, the modification factor for sections less than $72 \mathrm{~mm}$ in depth and for short term loads are 0.856 and 0.571 respectively. Table 3 shows the grade bending stresses calculated for clear and finger jointed timber specimens.

\subsection{Compressive strength parallel to grain}

Table 4 presents the results of the compression parallel to grain test. Fig. 13 compares the 
compressive strength variations of clear and timber jointed species. The strength reduction of Satin, Mahogani, Jak and Pinus is less than 20\%. Jak is found to be the most suitable species for finger jointing being able to withstand the compression most. The compressive strength obtained has to be multiplied by 0.571 , modification factor for very short-term loads given in BS 5268-2, to obtain the corresponding grade compressive stress. Table 4 summarizes the grade stresses of the specimens when under compression parallel to grain.

\subsection{Compressive strength perpendicular to grain}

Table 5 presents the results of the compression perpendicular to grain test. Fig. 14 compares the compressive strength variations of clear and finger jointed species. Strength of all finger jointed species except Jak is higher than that of clear timber. Therefore, finger jointed sections of most timber species can withstand compression perpendicular to grain better. Based on the modification factor given in BS 5268-2 for very short-term loads, the strength has to be multiplied by 0.571 to obtain the grade compressive stress. Table 5 summarizes compression perpendicular to grain grade stresses.
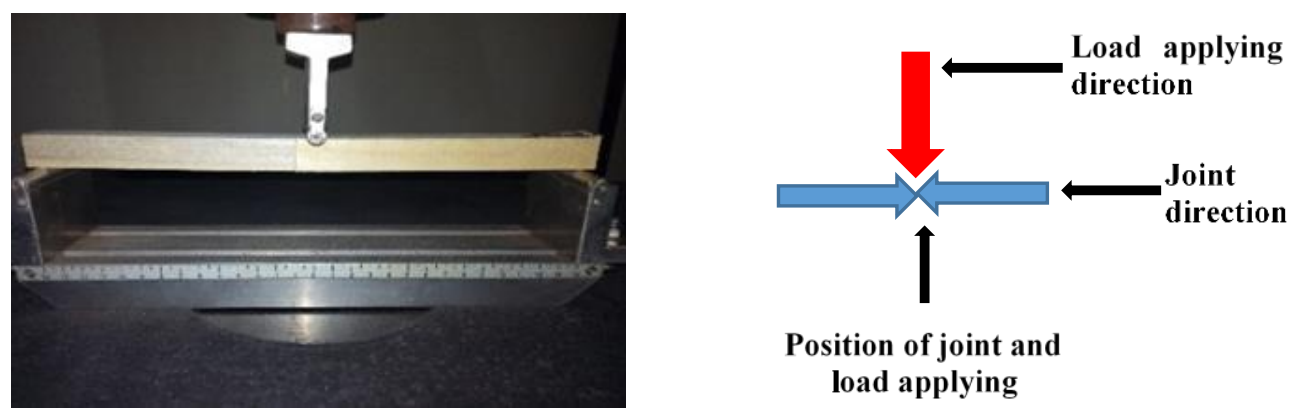

\section{Position of joint and load applying}

Fig. 8. Three-point bending test
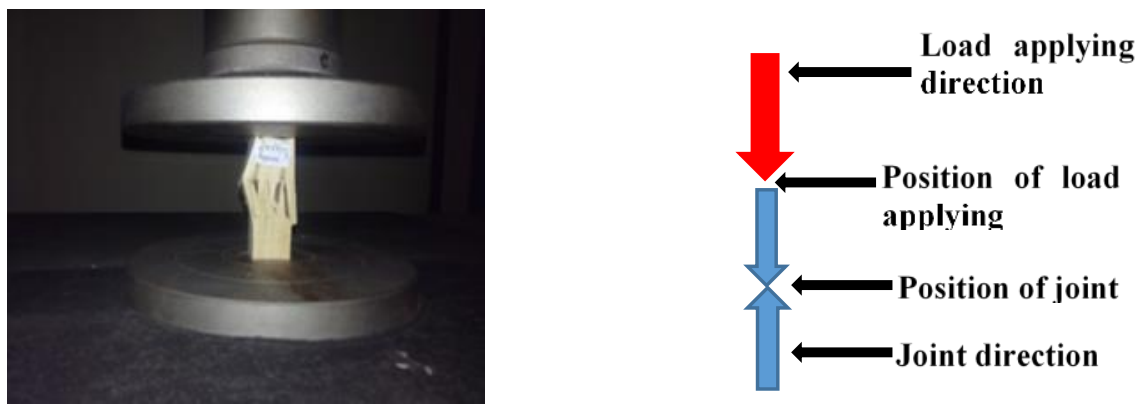

Fig. 9. Compression parallel to grain test
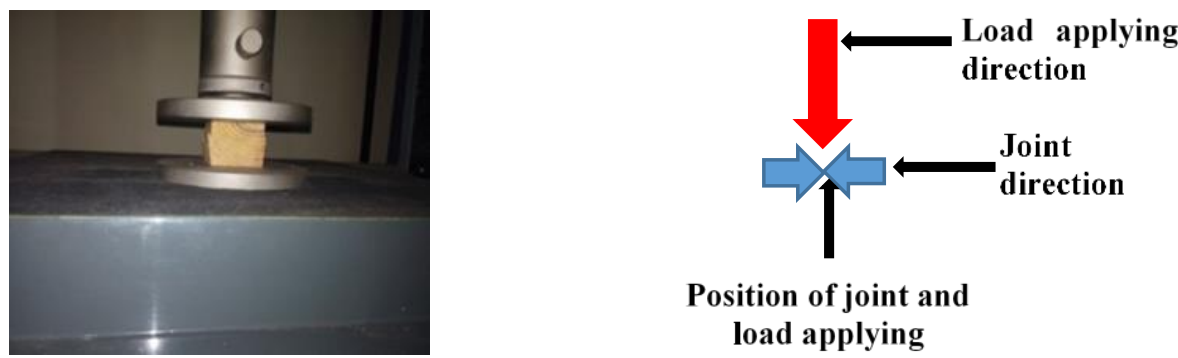

\section{Position of joint and \\ load applying}

Fig. 10. Compression perpendicular to grain test 

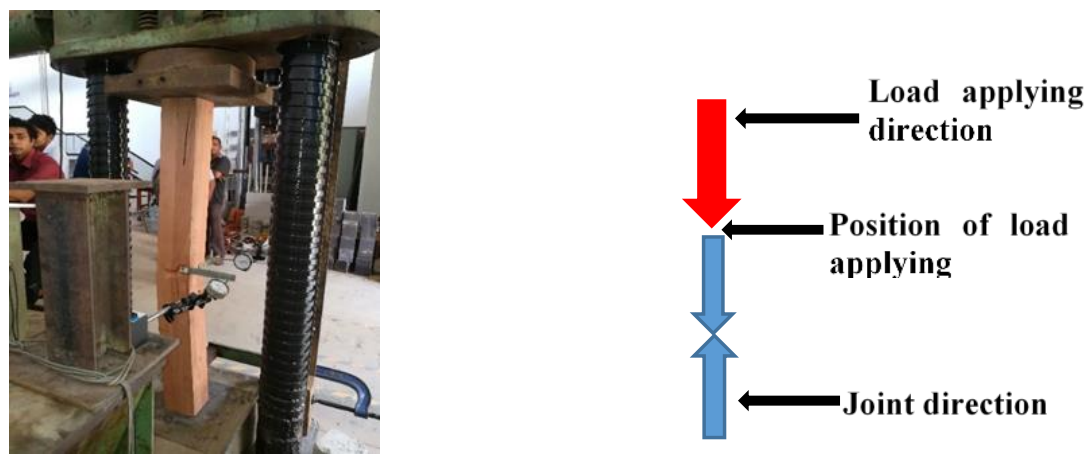

Fig. 11. Compression parallel to grain test

Table 3. Bending test results

\begin{tabular}{lccccc}
\hline & \multicolumn{3}{c}{ Bending strength } & \multicolumn{2}{c}{ Grade stress } \\
\cline { 2 - 5 } Species & $\begin{array}{c}\text { Clear } \\
\left(\mathrm{N} / \mathrm{mm}^{2}\right)\end{array}$ & $\begin{array}{c}\text { Finger Jointed } \\
\left(\mathrm{N} / \mathrm{mm}^{2}\right)\end{array}$ & $\begin{array}{c}\text { Strength } \\
\text { Reduction } \%\end{array}$ & $\begin{array}{c}\text { Clear } \\
\left(\mathrm{N} / \mathrm{mm}^{2}\right)\end{array}$ & $\begin{array}{c}\text { Finger Jointed } \\
\left(\mathrm{N} / \mathrm{mm}^{2}\right)\end{array}$ \\
\hline Teak & 26.02 & 23.20 & 10.84 & 13.97 & 10.40 \\
Satin & 27.94 & 25.28 & 9.50 & 24.12 & 20.93 \\
Mahogany & 24.59 & 16.64 & 32.34 & 8.93 & 7.72 \\
Jak & 30.58 & 17.49 & 42.82 & 8.53 & 8.40 \\
Kumbuk & 25.77 & 13.26 & 48.54 & 16.87 & 11.53 \\
Grandis & 29.39 & 16.09 & 45.25 & 8.92 & 7.74 \\
Pine & 20.86 & 16.80 & 19.43 & 9.08 & 8.80 \\
\hline
\end{tabular}

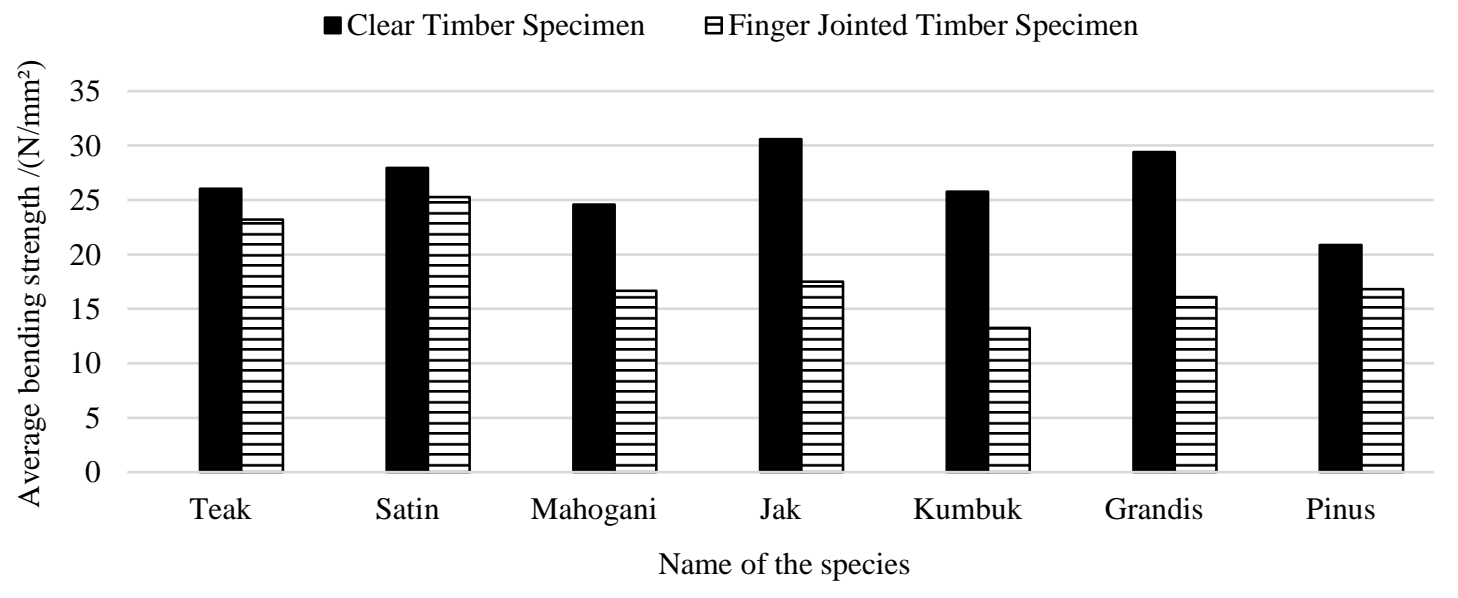

Fig. 12. Comparison of the average bending strength of different timber species 
Table 4. Compression parallel to grain test results

\begin{tabular}{lccccc}
\hline & \multicolumn{2}{c}{ Compressive strength parallel to grain } & \multicolumn{2}{c}{ Grade stress } \\
\cline { 2 - 6 } Species & $\begin{array}{c}\text { Clear } \\
\left(\mathrm{N} / \mathrm{mm}^{2}\right)\end{array}$ & $\begin{array}{c}\text { Finger Jointed } \\
\left(\mathrm{N} / \mathrm{mm}^{2}\right)\end{array}$ & $\begin{array}{c}\text { Strength } \\
\text { Reduction } \%\end{array}$ & $\begin{array}{c}\text { Clear } \\
\left(\mathrm{N} / \mathrm{mm}^{2}\right)\end{array}$ & $\begin{array}{c}\text { Finger Jointed } \\
\left(\mathrm{N} / \mathrm{mm}^{2}\right)\end{array}$ \\
\hline Teak & 24.45 & 18.20 & 25.54 & 12.71 & 11.33 \\
Satin & 42.21 & 36.62 & 13.24 & 13.64 & 12.35 \\
Mahogany & 15.62 & 13.51 & 13.51 & 12.01 & 8.13 \\
Jak & 14.93 & 14.70 & 1.53 & 14.94 & 8.54 \\
Kumbuk & 29.53 & 20.17 & 31.68 & 12.59 & 6.48 \\
Grandis & 15.61 & 13.55 & 13.22 & 14.35 & 7.86 \\
Pine & 15.89 & 15.40 & 3.04 & 10.19 & 8.21 \\
\hline
\end{tabular}

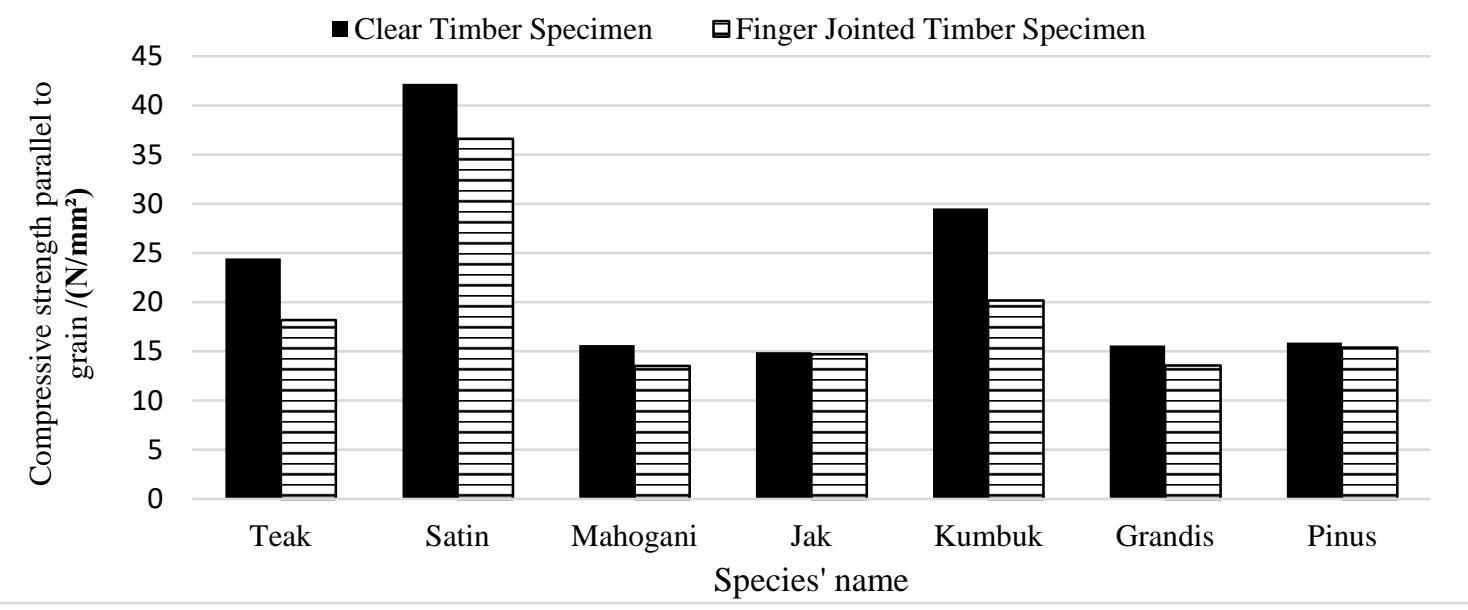

Fig. 13. Comparison of the average compressive strength parallel to grain of different timber species

Table 5. Compressive strength perpendicular to grain

\begin{tabular}{lccccc}
\hline & \multicolumn{2}{c}{ Compressive strength parallel to grain } & \multicolumn{2}{c}{ Grade stress } \\
\cline { 2 - 5 } Species & $\begin{array}{c}\text { Clear } \\
\left(\mathrm{N} / \mathrm{mm}^{2}\right)\end{array}$ & $\begin{array}{c}\text { Finger Jointed } \\
\left(\mathrm{N} / \mathrm{mm}^{2}\right)\end{array}$ & $\begin{array}{c}\text { Strength } \\
\text { Reduction } \%\end{array}$ & $\begin{array}{c}\text { Clear } \\
\left(\mathrm{N} / \mathrm{mm}^{2}\right)\end{array}$ & $\begin{array}{c}\text { Finger Jointed } \\
\left(\mathrm{N} / \mathrm{mm}^{2}\right)\end{array}$ \\
\hline Teak & 8.53 & 10.08 & -18.13 & 4.88 & 5.76 \\
Satin & 15.51 & 17.16 & -10.66 & 8.86 & 9.80 \\
Mahogany & 7.85 & 8.13 & -3.66 & 4.48 & 4.65 \\
Jak & 13.43 & 11.03 & 17.90 & 7.67 & 6.30 \\
Kumbuk & 7.71 & 8.28 & -7.31 & 4.41 & 4.73 \\
Grandis & 5.14 & 5.38 & -4.72 & 2.94 & 3.07 \\
Pine & 6.06 & 7.72 & -27.39 & 3.46 & 4.41 \\
\hline
\end{tabular}




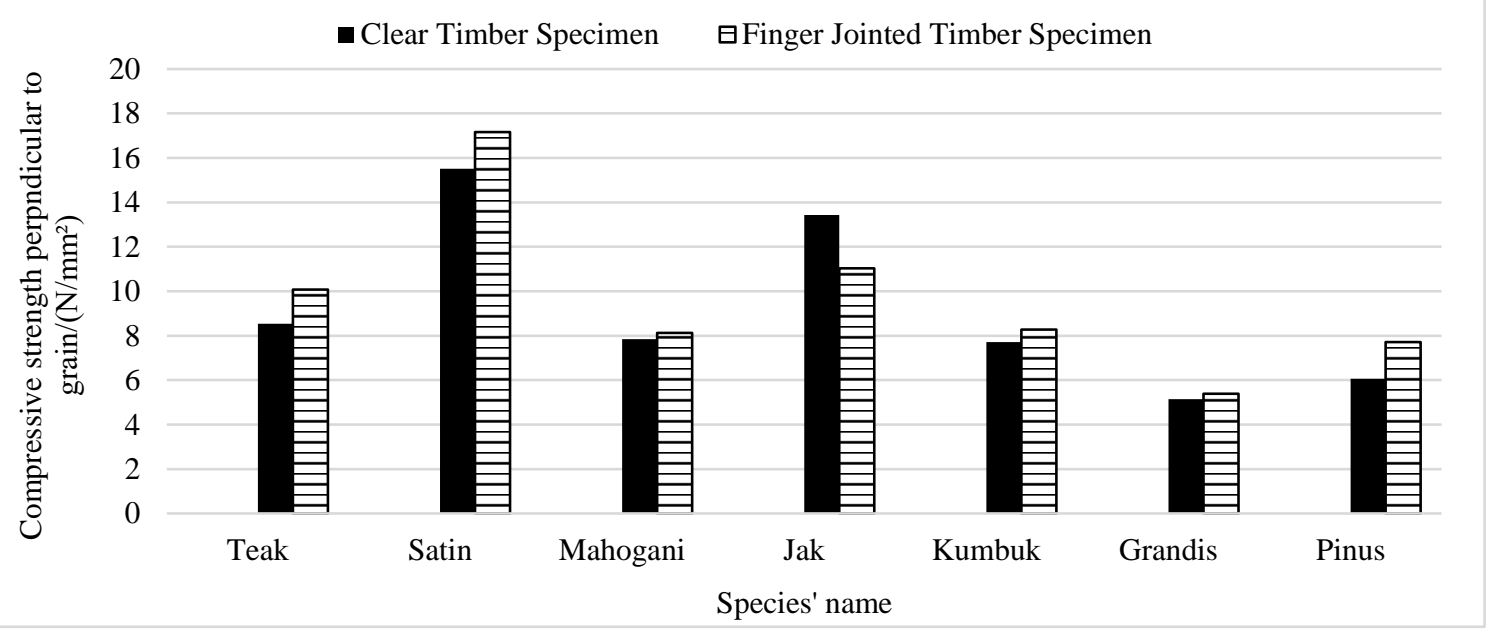

Fig. 14. Comparison of the average compressive strength perpendicular to grain of different timber species

\subsection{Modulus of elasticity (MOE)}

Modulus of Elasticity is an indicator for stiffness of the wood and only applies to conditions within elastic limit [8]. It is the ratio of stress per unit area to the deformation per unit length. It can be derived from compression test, flexural (Bending) test or tension test [9]. Flexural test results at serviceability state are used to obtain the MOE in this study. Average MOE for clear timber specimen and the finger jointed timber specimen which were obtained by the three-point bending test are included in Table 6 and MOE reduction percentage can be identified. MOE for Teak, Jak, Grandis and Satin are not reduced more than $3 \%$ compared with clear timber. Fig. 15 compares the MOE variations.

\subsection{Compression of specimens of structural scale}

This category belongs to evaluation of compressive strength of large scale (non-standard) timber specimens using Grandis and Pine timber and results for the ultimate capacities are shown in Table 7.

The compressive strengths of finger jointed specimens of Pine and Grandis, which were with structural scale shows reduction of $80.29 \%$ and $72.58 \%$, compared to clear timber section, respectively. The test was also carried out on sections jointed with glue. The test results reveal that the compression capacities of normal glue jointed Pine and Grandis shows 70.89\% and $72.16 \%$ reduction compared to clear timber section, respectively. Both test results indicate that there is no significant variation in the ultimate capacity of both glued and finger jointed timber species. However, it is recommended to carry out further tests on structural scale specimens for different species.

\subsection{Results of economic analysis}

Cost for finger joint manufacturing is similar for all the specimen because timber waste are used for it and there is not added any cost for timber material. Because those are the waste of timber material which were used for regular timber productions in sawn mill. The case is similar for glued joint. According to Fig. 14 finger joint preparation from timber waste of Teak timber is the most effective because cost reduction percentage is $13.19 \%$. Satin and Kumbuk also can be used for finger joint manufacturing because they have minimum cost increment percentage as $23.18 \%, 27.91 \%$ respectively. The variation of costs is shown in Fig. 16. It is taken that $1 \mathrm{US} \$=179.80 \mathrm{LKR}$ at the current rate of Central Bank of Sri Lanka (July, 2019). 
Table 6. Results for modulus of elasticity

\begin{tabular}{lccc}
\hline Species & $\begin{array}{c}\text { Clear Timber Specimen } \\
(\mathrm{MPa})\end{array}$ & $\begin{array}{c}\text { Finger Jointed Timber } \\
\text { Specimen } \\
(\mathrm{MPa})\end{array}$ & $\begin{array}{c}\text { MOE Reduction } \\
\text { Percentage } \\
\%\end{array}$ \\
\hline Teak & 8865.07 & 8796.66 & 0.77 \\
Satin & 9703.65 & 9493.32 & 2.17 \\
Mahogany & 6208.59 & 5552.56 & 10.57 \\
Jak & 5537.37 & 5391.96 & 2.63 \\
Kumbuk & 5225.88 & 4383.83 & 16.11 \\
Grandis & 5375.64 & 5286.38 & 1.66 \\
Pine & 5361.99 & 6657.08 & -24.15 \\
\hline
\end{tabular}

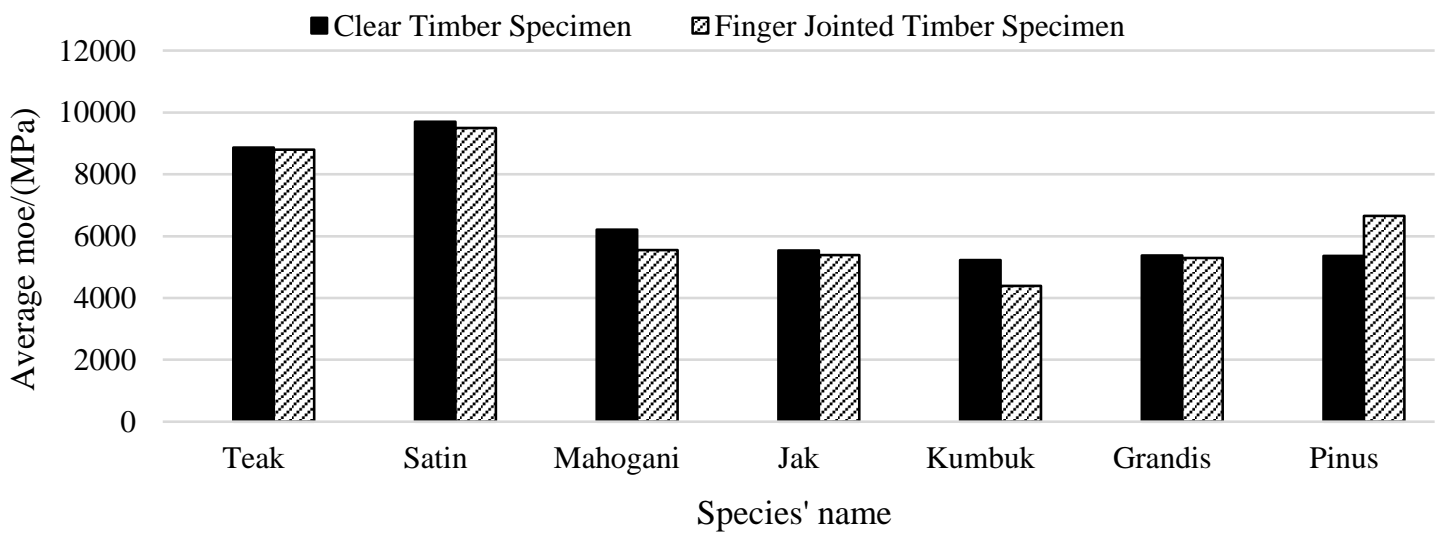

Fig. 15. Comparison of the MOE of different timber species

Table 7. Ultimate compression capacities of Pine and Grandis

\begin{tabular}{lc}
\hline Type & Ultimate compression capacity $\left(\mathrm{N} / \mathrm{mm}^{2}\right)$ \\
\hline Pine-Clear & 11.675 \\
Pine-Glued joint & 3.405 \\
Pine-Finger joint & 2.300 \\
Grandis-Clear & 12.930 \\
Grandis-Glued joint & 3.600 \\
Grandis- Finger joint & 3.545 \\
\hline
\end{tabular}

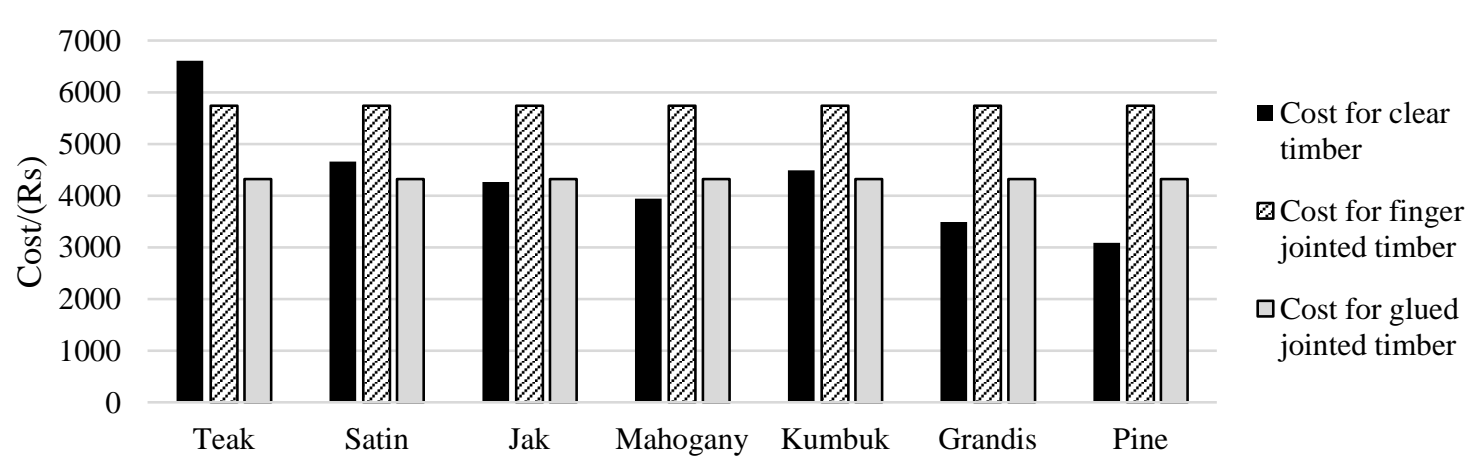

Fig. 16. Comparison of timber manufacturing cost 


\section{Conclusions}

Tests were carried out on finger jointed timber species commonly available in Sri Lanka to find out their bending strength, compressive strength and modules of elasticity.

It was ensured that Satin, Teak and Pine timber which have minimum bending strength reduction as $9.5 \%, 10.84 \%$ and $19.45 \%$ respectively compared to clear timber are effective to manufacture finger jointed timber element to withstand bending. Compressive strength parallel to grain reduction was found to be only $1.53 \%$ of that of clear specimens for Jak and therefore it is the most suitable species to use for finger joining. Satin, Grandis and Pine also have 13.24\%, 13.22\% and $3.04 \%$ strength reduction which are also suitable for withstand compression parallel to grain after Jak. Compressive strength perpendicular to grain values were found to be higher than clear timber other than Jak. Higher increment is shown by Teak and Pine as $18.13 \%$ and $27.39 \%$ that of clear timber. MOE values reduction was found to be less than $3 \%$ of that of clear timber for Teak, Grandis, Satin and Jak and Pine has 24,15\% increment due to the material property.

Test results reveal that the structural properties of timber waste collecting from Satin, Grandis and Pine get significantly improved when they are finger jointed. Consequently, finger jointed timber species which can withstand both bending and compression can be used to manufacture short timber sections such as beams, struts etc. Finger jointed Kumbuk is the timber species least suited for structural applications.

Test which was done on 1000 $\mathrm{mm} \times 100 \mathrm{~mm} \times 100 \mathrm{~mm}$ structural scale members of Grandis and Pine was led to think that, finger joint large-scale timber members are poor to withstand axial compression and several number of finger joints are not effective for compression member.

Economic analysis proofed that finger joining of Teak timber by using timber waste is only the cost effective. When consider the other species, it is not cost effective to manufacture finger joint in Sri Lanka because scale of the local finger joint manufacturing industry is small and it consumes higher labor cost and higher finishing cost. But according to the STC recommendation, the finger jointed product can be sold for two times higher price to the production cost. It is due to the high quality of the appearance compared with clear timber product and consumers' interests on that.

However, compared to other timber species, finger jointed Teak timber is structurally as well as economically suitable for use in construction industry in Sri Lanka by utilizing the waste timber.

The focus of this study was on waste timber utilization in construction. However, it is exposed that there is a need for future research to understand the performance of finger jointed timber species made with metal connectors, mechanical improvements etc. These future studies could be used to determine the mechanical properties of timber species of different sectional dimensions, limitations of the dimensions that can be used for finger jointing and the durability of the joints bonded using epoxy adhesives under higher load bearing capacities.

\section{Acknowledgments}

The authors wish to thank Mr. C. K. Muthumala, Manager Research \& Development and staff of the Training Division, State Timber Corporation, Battaramulla, Sri Lanka for the support they extended during specimen preparation and laboratory tests.

\section{References}

[1] Ruwanpathirana BS (2007) Timber utilization in Sri Lanka.

http://www.timber.lk/timberindustry/publish/Timb er\%20Utilization\%20in\%20Sri\%20Lank\%20presentation.pdf. (last view 05 April 2017)

[2] Ayarkwa J, Hirashima Y, Sasaki Y (2000) Effect of finger geometry and end pressure on the flexural properties of finger-jointed tropical African hardwoods. Forest Product Journal 50(11/12): 5363.

[3] Ronald WJ (1981) Finger-jointed wood products. Research Paper, Department of Agriculture, University of United States.

[4] Universal Forest Products, Inc (2002) Structural finger jointed lumber. 
http://www.ufpi.com/ /media/57c7b1d51869400a 9c7e10633f1e654c.pdf (last view 12 September 2017).

[5] Cecilia B (2003) Structural performance offingerjointed black spruce lumberwith different joint configurations.

https://www.researchgate.net/publication/2376770 97_Structural_performance_of_fingerjointed_black_spruce_lumber_with_different_join t configurations (last view 05 April 2017).

[6] Yeoh EC, Mohamed Z Strength of structural timber members with finger-joints and metal plate connector. M.Sc. Thesis. Timber Engineering Laboratory, Kolej Universiti Teknologi Tun Hussein Onn, 1999.
[7] State Timber Corporation. Annual Report 20052006. Battaramulla, Sri Lanka, 2006.

[8] Record SJ (1914) The mechanical properties of wood, create space independent publishing platform.

http://www.basiccarpentrytechniques.com/The $\% 2$ 0Mechanical\%20Properties\%20of\%20Wood/The $\% 20$ Mechanical $\% 20$ Properties $\% 20$ of $\% 20$ Wood $\%$ 201.htm (last view 05 April 2017)

[9] Sathesrajkumar S, De Silva S, De Silva GHMJ, Muthumala CK. Performance of finger jointed timber boards with different joint configurations. Sustainable Built Environment: $7^{\text {th }}$ International Conference, 16-18 December 2016 Kandy, Sri Lanka. 